\title{
High hopes for Brazilian science
}

\section{As President Lula prepares to leave office, researchers expect that innovation will invigorate the economy.}

\section{BRASILIA, BRAZIL}

It is rare that a head of state ends a second term with approval ratings of around $80 \%$. But when Brazilian President Luiz Inácio Lula da Silva took to the stage last month at a science-policy conference, his popularity was clear: more than 3,000 scientists, administrators and industrialists stood to applaud him and to cheer his science minister of five years, Sérgio Rezende.

With a government convinced that science is an essential part of a growing economy, Brazilian researchers have never known better times, and the 4th National Conference on Science, Technology and Innovation in Brasilia on 26-28 May was brimming with optimism for an even sunnier future. At the conference, Lula signed a series of bills that will help to sustain his legacy of science investment after he and Rezende leave office on 1 January 2011. The bills, if enacted by the National Congress, will increase funding for postdocs and establish three new biodiversity research centres, with the overall goal being to further reduce the country's brain drain and perhaps even reverse it.

The conference will deliver a consensus statement from Brazil's top scientific brass on where its research programme should focus over the next decade. The document is likely to be influential, says Luiz Davidovich, a director of the Brazilian Academy of Sciences and a physicist at the Federal University of Rio de Janeiro. "The conference is the first time that those at the heart of science, and those tangentially involved, have all been brought together - and at a point when things are really taking off," adds Carlos Henrique de Brito Cruz, the scientific director of FAPESP, São Paulo's state research foundation. The consensus statement, due to be published in two months' time, will be sent to all of the presidential candidates.

One prominent suggestion expected to be in the statement is the fostering of centres of excellence. "We need to look after our Pelés as well as build more football pitches," says de Brito Cruz. "The current focus of funding is on new centres, but there is no specific programme to fund research stars." Another proposal is to provide more incentives for multinational companies to conduct research and development in Brazil.

These policies would build on a well-funded foundation. The Brazilian Ministry of Science and Technology says that after Lula took office in 2003, total public and commercial funding for science and technology soared from 21.4 billion reais (US $\$ 11.4$ billion) to 43.1 billion reais in 2008 (or from $1.26 \%$ to $1.43 \%$ of Brazil's growing gross domestic product; GDP) - due in part to Lula, and to policies implemented by former president Fernando Henrique Cardoso.
Publications by Brazilians in peer-reviewed science journals have leapt from 14,237 in 2003 to 30,415 in 2008 , according to data analysts Thomson Reuters.

This is impressive not only in the context of Latin America but also compared with Russia, India and China, for example. In 2000, Brazil generated $43 \%$ of Latin America's peer-reviewed publications. Scientific output has since improved across the region, but in 2008, Brazilian publications made up 55\% of the total. Brazil has particular strengths in agricultural science; for example, in 2000, a consortium based in São Paulo became the first in the world to sequence the genome of a plant pathogen, the bacterium Xylella fastidiosa, which destroys citrus crops.

Brazil spends significantly more per researcher than China or Russia, according to its science ministry. "I believe we have reached a point where the sector will grow organically," says Rezende. "So the next person in charge will not have to do much."

Science is also doing well at the level of individual states, which provide a significant source of public funding, although efforts to boost science are patchy. Many states are looking to emulate wealthy São Paulo, which has the strongest scientific tradition. "There is an article from 1947 in the constitution of the state of São Paulo," explains de Brito Cruz. "It says

\section{Endangered-porpoise numbers fall to just 250}

At the northern end of the Gulf of California, where the Baja peninsula joins the rest of Mexico, the world's most endangered marine mammal is inching closer to extinction.

With adults only 1.5 metres long, the vaquita (Phocoena sinus), a rare porpoise found only in these waters, epitomizes the plight of small cetaceans, which bear the brunt of pollution, ship traffic and fishing because they live in rivers and coastal areas. In China, the Yangtze river dolphin (Lipotes vexillifer) was last seen in 2007 and is now considered extinct. The vaquita vulnerable to gill nets used by local fisherman - could be the next to go.
On the basis of data gathered in 2008 during an acoustic survey ${ }^{1}$ researchers now estimate that only $\mathbf{2 5 0}$ individuals of the species remain, a drop of $56 \%$ in just over a decade. The finding was presented this week at a scientific meeting of the International Whaling Commission in Agadir, Morocco.

"This information shows we don't have a lot of time to save the vaquita," says Timothy Ragen, executive director of the Marine Mammal Commission in Bethesda, Maryland, which part-funded the survey.

First documented in 1958, the vaquita is an elusive and poorly understood species. Genetic

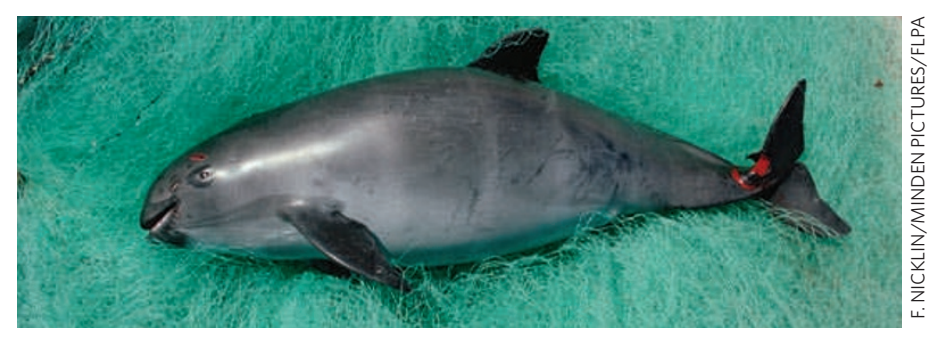

The diminutive vaquita is found only in the Gulf of California. analyses suggest that its ancestors were Southern Hemisphere porpoises that migrated north during the last ice age. Individuals travel in small groups and rarely attract attention by leaping or splashing.

In 1997, Tim Gerrodette, a marine biologist at the Southwest Fisheries Science Center in La Jolla, California, led the first comprehensive survey of the vaquita, estimating the population to be 567 individuals ${ }^{2}$. A decade later, another analysis ${ }^{3}$, based on 
